\title{
ALGORITMA DIJKSTRA : TEORI DAN APLIKASINYA
}

\author{
ABDUL ZAKI \\ Program Studi Magister Matematika, \\ Fakultas Matematika dan Ilmu Pengetahuan Alam, Universitas Andalas, \\ Kampus UNAND Limau Manis Padang, Indonesia, \\ email : zakimathua@yahoo.com
}

\begin{abstract}
Abstrak. Algoritma Dijkstra merupakan algoritma yang dipakai dalam penentuan lintasan terpendek dari suatu titik tertentu ke setiap titik lain pada suatu graf. Lintasan terpendek untuk suatu titik tertentu dengan titik lainnya diperoleh dari pohon pembangun yang memiliki nilai minimum. Pada makalah ini akan dibahas teori dari algoritma Dijkstra serta penerapannya dalam menentukan lintasan terpendek.
\end{abstract}

Kata Kunci: Pohon pembangun, algoritma Dijkstra, lintasan terpendek

\section{Pendahuluan}

Teori graf adalah bagian dari disiplin ilmu matematika diskrit yang sangat berguna untuk mengembangkan model-model terstruktur dalam berbagai situasi dan sangat banyak diaplikasikan dalam kehidupan sehari-hari. Titik dan garis merupakan alat yang dipakai dalam teori graf. Sebagai contoh, titik merupakan representasi dari orang-orang pada suatu keluarga dan garis merupakan representasi dari hubungan antara dua orang dalam keluarga tersebut. Salah satu aplikasi teori graf adalah penentuan lintasan terpendek pada suatu graf. Aplikasi penentuan lintasan terpendek merupakan salah satu persoalan optimasi karena tujuannya adalah untuk menentukan panjang lintasan yang minimum dari satu titik ke titik lain.

Graf yang dipakai dalam penentuan lintasan terpendek adalah graf berbobot, yaitu graf yang untuk setiap sisinya memiliki nilai sehingga panjang lintasan dari suatu titik ke titik lain merupakan jumlah dari nilai-nilai pada setiap sisinya. Panjang lintasan pada lintasan terpendek dari suatu titik ke titik lain dapat disebut dengan jarak antara dua titik.

Penentuan lintasan terpendek yang akan dibahas pada makalah ini menggunakan algoritma Dijkstra yang dikembangkan oleh Edsger Wybe Dijkstra pada tahun 1959. Algoritma Dijkstra merupakan algoritma yang dipakai dalam penentuan lintasan terpendek dari suatu titik tertentu ke setiap titik lain pada suatu graf. Pengaplikasian algoritma Dijkstra dalam menentukan lintasan terpendek bertujuan agar lintasan terpendek dari suatu titik ke titik lain dapat dilakukan dalam satu kali algoritma saja. Konsep dari algoritma Dijkstra adalah membentuk pohon Dijkstra pada suatu graf $G$ terhubung dengan pengulangan sebanyak $|V(G)|-1$ sedemikian sehingga pohon Dijkstra setelah pengulangan terakhir merupakan pohon pembangun (spanning tree) dari graf $G$. 


\section{Definisi dan Terminologi Graf}

Berikut disajikan definisi dan terminologi dalam teori graf yang digunakan pada makalah ini, yang dikutip dari [1].

Suatu graf $G=(V, E)$ didefinisikan sebagai suatu pasangan himpunan $\left(V(G), E(G), \psi_{G}\right)$, di mana $V(G)$ adalah himpunan tak kosong dari elemen yang disebut titik (vertex), $E(G)$ adalah himpunan sisi (edge) dan $\psi_{G}$ adalah suatu fungsi keterkaitan (incidency function) yang mengaitkan setiap sisi di $G$ dengan pasangan titik di $G$. Banyaknya titik di $G$ disebut orde (order) dari $G$ yang dinotasikan dengan $|V(G)|=P$, dan banyaknya sisi pada $G$ disebut ukuran (size) dari $G$ yang dinotasikan dengan $|E(G)|=Q$.

Misal terdapat graf $G=(V, E)$ dengan $v_{i}, v_{j} \in V(G)$. Jika untuk setiap dua titik $v_{i}, v_{j} \in V(G)$ terdapat lintasan yang menghubungkan kedua titik tersebut, maka graf $G$ dikatakan graf terhubung (connected graph).

Graf yang digunakan untuk menentukan lintasan terpendek adalah graf terhubung. Lintasan (path) merupakan hasil yang akan diperoleh dari penelitian ini dengan memperhatikan bahwa titik awal $\left(v_{0}\right)$ tidak sama dengan titik akhir $\left(v_{k}\right)$.

Suatu barisan yang memuat titik-titik dan sisi-sisi bergantian $W=$ $v_{0} e_{1} v_{1} e_{2} \ldots e_{k} v_{k}$ pada graf terhubung $G$ dinamakan jalan (walk). Misalkan $W=v_{0} e_{1} v_{1} \ldots e_{k} v_{k}$ adalah jalan, untuk setiap sisi-sisi $e_{1}, e_{2}, \ldots, e_{k}$ dan titik-titik $v_{0}, v_{1}, \ldots, v_{k}$. Jika $e_{i} \neq e_{j}, i, j=1,2, \ldots, k$ dan $v_{s} \neq v_{t}, s, t=0,1, \ldots, k$, maka $W$ adalah lintasan- $\left(v_{0}, v_{k}\right)$. Dapat dilihat bahwa lintasan merupakan jalan yang setiap titik dan sisinya hanya dilewati satu kali.

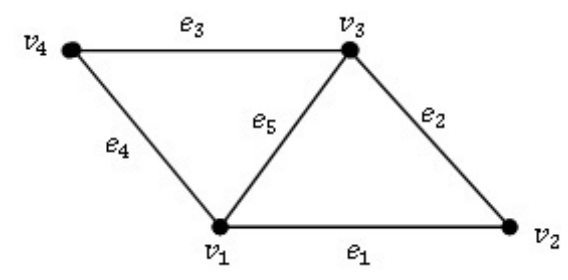

Gambar 1. Ilustrasi Jalan dan Lintasan pada Graf $G$

Graf $G$ pada Gambar 1 memiliki jalan yang dinotasikan dengan $W$ dan lintasan yang dinotasikan dengan $P$ sebagai berikut:

$$
\begin{aligned}
W & =v_{1} e_{5} v_{3} e_{2} v_{2} e_{1} v_{1} e_{5} v_{3} e_{3} v_{4} e_{4} v_{1}, \\
P & =v_{1} e_{1} v_{2} e_{2} v_{3} e_{3} v_{4} .
\end{aligned}
$$

\subsection{Graf Berbobot}

Graf berbobot sangat banyak digunakan dalam aplikasi teori graf. Secara sederhana, graf berbobot adalah graf yang setiap sisinya diberikan suatu nilai atau bobot. Nilai atau bobot tersebut dapat bernilai positif atau negatif, akan tetapi pada kasus lintasan terpendek, bobot harus bernilai positif karena berhubungan dengan panjang lintasan [1]. 
Definisi 2.1. [1] Pengaitan suatu bilangan riil $w(e)$ untuk setiap sisi e di graf $G$ disebut bobot (weighted). Graf $G$ yang memiliki nilai w(e) pada sisi-sisinya dinamakan graf berbobot (weighted graph).

Sebagai contoh, misalkan kota-kota di Sumatera Barat direpresentasikan sebagai titik-titik pada graf $S$, yaitu Padang $\left(v_{p d}\right)$, Bukittinggi $\left(v_{b t}\right)$, Padang Panjang $\left(v_{p p}\right)$, Payakumbuh $\left(v_{p y}\right)$, Pariaman $\left(v_{p r}\right)$, Solok $\left(v_{s l}\right)$ dan Sawahlunto $\left(v_{s w}\right)$, seperti yang ditampilkan pada Gambar 2. Di sini bobot pada graf $S$ didefinisikan sebagai jarak tempuh antara kedua kota.

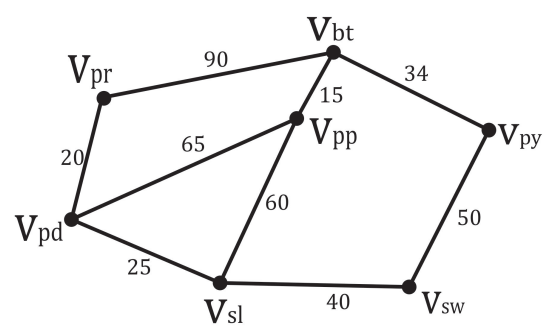

Gambar 2. Graf $S$ yang Merupakan Graf Berbobot.

Pada Gambar 2, terdapat pengaitan suatu bilangan real $w(e)$ untuk setiap sisi pada graf $S$. Pada graf $S$ didefinisikan bahwa bobot untuk $w\left(v_{p d} v_{s l}\right)=25$ artinya jarak antara kota Padang dan kota Solok adalah 25. Hal serupa juga berlaku untuk setiap titik yang terhubung lainnya.

Definisi 2.2. [1] Panjang lintasan pada graf berbobot adalah jumlah bobot pada suatu lintasan-( $u, v)$ yang dinotasikan dengan $l(u, v)$. Misalkan $v_{1} v_{2} \ldots v_{n}$ adalah suatu lintasan dengan titik awal $v_{1}$ dan titik akhir $v_{n}$, maka panjang lintasan- $\left(v_{1}, v_{n}\right)$ dinyatakan oleh

$$
l\left(v_{1}, v_{n}\right)=\sum_{i=1,2, \ldots, n-1} w\left(v_{i} v_{i+1}\right) .
$$

Pada Gambar 2, terdapat banyak kemungkinan lintasan antara Padang dan Payakumbuh. Misalkan $P\left(v_{p d}, v_{p y}\right)=v_{p d} v_{s l} v_{s w} v_{p y}$, maka berdasarkan Persamaan (2.1), panjang lintasan $P$ adalah

$$
\begin{aligned}
l\left(v_{p d}, v_{p y}\right) & =w\left(v_{p d} v_{s l}\right)+w\left(v_{s l} v_{s w}\right)+w\left(v_{s w} v p y\right) \\
& =25+40+50 \\
& =115
\end{aligned}
$$

\subsection{Pohon Pembangun (Spanning Tree)}

Secara sederhana pohon (tree) dari suatu graf merupakan subgraf yang tidak memuat sebuah siklus (cycle dan pohon pembangun spanning tree merupakan subgraf dari pohon tersebut [3]. 
Definisi 2.3. [3] Suatu graf yang tidak memuat siklus dikatakan acyclic. Hutan (forest) merupakan graf acyclic. Pohon adalah graf acyclic terhubung. Daun (leaf) merupakan titik (vertex) yang berderajat 1. Subgraf pembangun (spanning subgraph) dari $G$ merupakan suatu subgraf yang titik-titiknya adalah $V(G)$. Suatu pohon pembangun merupakan subgraf pembangun yang berbentuk pohon.

Bobot setiap sisi sangat diperlukan dalam penentuan nilai (cost) antara dua titik tertentu pada suatu graf. Pohon pembangun dari suatu graf terhubung yang memiliki bobot total minimum dapat dikatakan sebagai pohon pembangun minimum. Pohon pembangun minimum ini dapat digunakan untuk menentukan lintasan terpendek dari suatu titik tertentu ke titik lainnya pada graf [3].

\subsection{Lintasan Terpendek}

Penentuan lintasan terpendek pada sebuah graf merupakan salah satu persoalan optimasi. Graf yang digunakan dalam penentuan lintasan terpendek adalah graf berbobot.

Definisi 2.4. [1] Lintasan terpendek (shortest path) dengan titik awal $v_{0}$ dan titik akhir $v_{k}$ didefinisikan sebagai lintasan yang memiliki panjang lintasan yang minimum dari $v_{0}$ ke $v_{k}$.

Misalkan $v_{0}$ dinyatakan sebagai titik awal dan $v_{k}$ sebagai titik akhir. Jika terdapat $m$ lintasan yang berbeda, maka lintasan terpendek antara $v_{0}$ dan $v_{k}$ dinyatakan oleh $P_{t}$, dimana $P_{t}$ adalah lintasan ke $-t$ dari $v_{0}$ ke $v_{k}$, dengan

$$
l_{t}\left(v_{0}, v_{k}\right)=\min _{i=1, \ldots, m} l_{i}\left(v_{0}, v_{k}\right) .
$$

Pada Gambar 2, dapat dilihat bahwa terdapat enam buah lintasan dari $v_{p d}$ ke $v_{p y}$ dengan panjang lintasan yang berbeda. Lintasan terpendek dari titik $v_{p d}$ ke $v_{p y}$ adalah $v_{p d} v_{p p} v_{b t} v_{p y}$ dengan jarak $d\left(v_{p d}, v_{p y}\right)=114$. Pada kasus ini dimungkinkan terdapat dua atau lebih lintasan terpendek dengan panjang lintasan yang sama tetapi jalurnya berbeda. Dengan memperhatikan lintasan terpendek dari $v_{p p}$ ke $v_{s} w$, maka dapat dilihat bahwa lintasan $v_{p p} v_{b t} v_{p y} v_{s w}$ mempunyai jarak 100 dan lintasan $v_{p p} v_{s l} v_{s w}$ juga mempunyai jarak 100. Jarak dari kedua lintasan tersebut sama, tetapi lintasan yang dilalui berbeda. Pemilihan lintasan terpendek dari $v_{p p}$ ke $v_{s w}$ dilakukan dengan memilih salah satu [2].

Definisi 2.5. [1] Jarak (distance) pada graf berbobot adalah jumlah bobot minimum pada suatu lintasan- $(u, v)$, dinotasikan dengan $d(u, v)$.

Berdasarkan definisi panjang lintasan dan Definisi 2.5, jarak pada suatu graf berbobot dapat dikatakan sebagai panjang lintasan dari lintasan terpendek.

\section{Algoritma Dijkstra}

Algoritma Dijkstra merupakan algoritma yang dipakai dalam penentuan lintasan terpendek dari suatu titik tertentu ke setiap titik lain pada suatu graf. Algoritma ini dikembangkan oleh Edsger Wybe Dijkstra pada tahun 1959. Lintasan terpendek 
untuk suatu titik tertentu dengan titik lainnya diperoleh dari pohon pembangun yang memiliki nilai minimum [2].

Strategi yang digunakan pada algoritma Dijkstra yaitu dengan membentuk suatu pohon Dijkstra yang diawali pada titik $v_{0}$, dengan menambahkan sisi terkait dan terdekat dengan titik $v_{0}$. Penambahan sisi dilakukan pada setiap pengulangan (iteration) dan dilakukan dengan menggunakan fungsi Dijkstra-nextEdge [2].

Definisi 3.1. [2] Fungsi Dijkstra-nextEdge didefinisikan sebagai berikut. Misalkan $X$ adalah himpunan sisi terkait yang telah ditambahkan. DijkstranextEdge $(G, X)$ memberikan nilai pada titik akhir sisi terkait yang titik ujungnya berderajat lebih dari satu (non-tree) dan memilih sisi yang titik ujungnya paling dekat dengan $v_{0}$. Jika titik yang terpilih lebih dari satu, maka pilih salah satu.

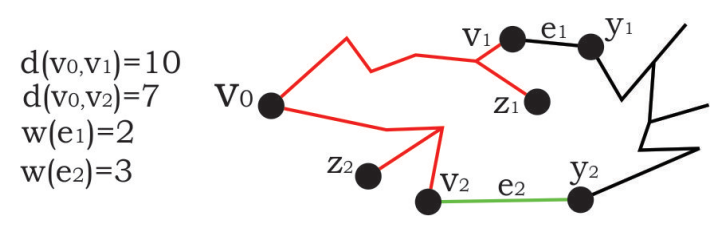

Gambar 3. Ilustrasi Fungsi Dijkstra-nextEdge $(G, X)$

Gambar 3 memperlihatkan bahwa $e_{1}$ dan $e_{2}$ merupakan sisi terkait yang titik ujungnya berderajat lebih dari satu. Kemudian sisi yang titik ujungnya paling dekat dengan $v_{0}$ adalah sisi $e_{2}$.

\section{Algoritma Lintasan Terpendek Dijkstra [2]}

Input : Graf berbobot $G$ dan titik awal $v_{0}$

Output : Pohon lintasan terpendek $T$ dengan titik awal $v_{0}$

- Inisialisasikan titik $v_{0}$ sebagai pohon $T$.

- Inisialisasikan $X$ sebagai himpunan sisi yang bertetangga dengan $v_{0}$

- Selama $X \neq \emptyset$

- Misalkan $e:=$ Dijkstra-nextEdge $(G, X)$

- Misalkan $v_{1}$ sebagai titik ujung dari sisi $e$ yang berderajat lebih dari satu.

- Tambahkan sisi $e$ dan titik $v_{1}$ pada pohon $T$

- Perbaharui pohon $T$

- Diperoleh pohon $T$ yang merupakan pohon pembangun dari $G$

Misalkan $d\left(v_{0}, v\right)$ menyatakan jarak dari titik awal $v_{0}$ ke $v$ untuk setiap titik $v$ pada pohon. Gambar 4 memperlihatkan penambahan sisi pada setiap pengulangan untuk membentuk pohon Dijkstra.

Angka pertama di dalam kurung menyatakan pengulangan dan angka kedua menyatakan $d\left(v_{0}, v\right)$ untuk setiap $v \in V(G)$. Pada pengulangan ke-1, sisi terkait yang titik ujungnya berderajat lebih dari satu adalah $v_{0} v_{1}$ dan $v_{0} v_{5}$. Titik $v_{1}$ memiliki nilai yang lebih rendah dari titik $v_{5}$ sehingga sisi yang ditambahkan adalah sisi $v_{0} v_{1}$. 


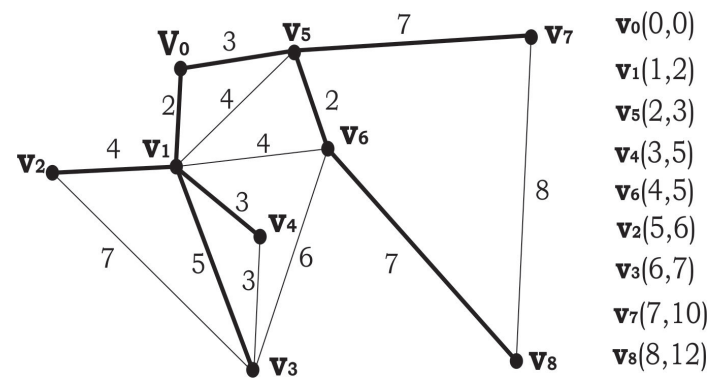

Gambar 4. Proses Penentuan Pohon Dijkstra pada Graf G

Pada pengulangan ke-2, sisi terkait yang titik ujungnya berderajat lebih dari satu adalah $v_{0} v_{5}, v_{1} v_{2}, v_{1} v_{3}, v_{1} v_{4}, v_{1} v_{6}, v_{1} v_{5}$. Sisi yang titik ujungnya paling dekat dengan $v_{0}$ adalah sisi $v_{1} v_{5}$ sehingga sisi tersebut ditambahkan ke pohon Dijkstra. Hal tersebut dilakukan untuk pengulangan selanjutnya sampai pohon Dijkstra yang terbentuk merupakan pohon pembangun dari graf $G$. Pada Gambar 4, sisi-sisi tebal adalah sisi-sisi dari lintasan terpendek dari titik $v_{0}$ ke titik lain di graf $G$ yang diperoleh dengan algoritma Dijkstra.

\subsection{Penghitungan Jarak}

Misalkan $w(e)$ menyatakan bobot dari sisi $e$ pada graf berbobot dan $w(q)$ menyatakan bobot dari sisi $q$ pada pohon yang terbentuk dan $v_{0}$ adalah titik awal yang dipilih untuk penentuan pohon Dijkstra. Jika $v$ adalah titik pangkal dengan nilai terendah dan $y$ sebagai titik ujung pada sisi $q$ yang terpilih, maka $d\left(v_{0}, y\right)=d\left(v_{0}, v\right)+w(q)$. Jadi, pada saat $q$ terpilih pada pengulangan ke- $i$ sebagai sisi yang ditambahkan pada pohon Dijkstra, $y$ haruslah menjadi titik dengan nilai minimum.

Definisi 3.2. [2] Misalkan e sebagai sisi terakhir yang ditambahkan pada pohon Dijkstra yang terbentuk dan $v$ merupakan titik pangkal pada sisi pohon e. P-Value dari sisi e yang dinotasikan oleh $P(e)$, diberikan oleh

$$
P(e)=d\left(v_{0}, v\right)+w(e)
$$

Jadi, Dijkstra-nextEdge $(G, X)$ memilih dan memberikan nilai pada titik akhir sisi $e$ sedemikian sehingga $P\left(e^{\star}\right)=\min _{e \in X} P(e)$. Dengan kata lain $e^{\star}$ merupakan sisi yang memiliki $P$-value yang minimum untuk sisi $e \in X$, dimana $X$ adalah himpunan sisi yang terkait dengan pohon T. $P$-value untuk setiap sisi $e$ dapat berubah pada setiap pengulangan.

\subsection{Uji Kebenaran Algoritma Dijkstra}

Teorema 3.3. [2] Misalkan $T_{j}$ adalah pohon Dijkstra setelah $j$ iterasi dari algoritma Dijkstra pada graf terhubung $G$, untuk $0 \leq j \leq|V(G)|-1$. Untuk setiap $v \in T_{j}$, lintasan- $\left(v_{0}, v\right)$ yang unik di $T_{j}$ adalah lintasan- $\left(v_{0}, v\right)$ terpendek di $G$. 
Bukti. Solusi trivial untuk $T_{0}$, karena pada saat $j=0$, pohon Dijkstra yang terbentuk hanya sebuah titik awal. Menggunakan induksi, diasumsikan untuk setiap $j, 0 \leq j \leq|V(G)|-2$, bahwa $T_{j}$ adalah benar. Misalkan sisi $e$ dengan titik pangkal $v_{1} \in T_{j}$ dan titik ujung $v_{2} \notin T_{j}$, sebagai sisi terkait yang ditambahkan ke pohon $T_{j}$ pada pengulangan ke $j+1$. Karena $v_{2}$ merupakan satu-satunya titik baru di $T_{j+1}$, maka lintasan- $\left(v_{0}, v_{2}\right) Q$ di $T_{j+1}$ adalah lintasan terpendek dari $v_{0}$ ke $v_{2}$ dengan panjang lintasan $Q$ adalah $P(e)$.

Selanjutnya akan ditunjukkan bahwa lintasan $Q$ merupakan lintasan yang unik. Artinya, tidak ada lintasan yang lebih pendek dari $Q$. Misalkan $R$ adalah lintasan$\left(v_{0}, v_{2}\right)$ yang lain di $G$. Notasikan panjang lintasan $Q$ dengan $l(Q)$ dan panjang lintasan $R$ dengan $l(R)$. Akan ditunjukkan $l(R) \geq l(Q)$. Misalkan sisi $f$ dengan titik pangkal $v_{3} \in T_{j}$ dan titik ujung $v_{4} \notin T_{j}$, dimana $f \notin T_{j}$. Misalkan lintasan $K$ adalah lintasan yang menghubungkan $v_{4}$ dengan $v_{2}$, artinya lintasan $K$ adalah bagian dari lintasan $R$.

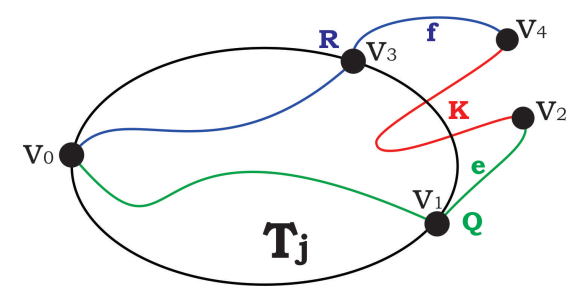

Gambar 5. Uji kebenaran Algoritma Dijkstra

Karena sisi $e$ sisi terkait dengan $T_{j}$ dan dipilih untuk ditambahkan ke $T_{j}$ pada pengulangan ke $j+1$, maka $P(e) \leq P(f)$. Perhatikan bahwa,

$$
\begin{aligned}
l(R)=d\left(v_{0}, v_{3}\right)+w(f)+l(K) & =P(f)+l(K) \\
& \geq P(e)+l(K) \geq P(e)=l(Q) .
\end{aligned}
$$

Jadi, karena $l(R) \geq l(Q)$ maka lintasan $Q$ merupakan lintasan unik yaitu tidak ada lintasan yang lebih pendek dari lintasan $Q$.

\section{Aplikasi Algoritma Dijkstra}

Algoritma Dijkstra dapat digunakan dalam menentukan lintasan terpendek dari satu titik tertentu ke setiap titik lain pada graf yang dibentuk. Banyak hal yang dapat diaplikasikan menggunakan algoritma Dijkstra, salah satunya adalah pemilihan lokasi terdekat diantara beberapa lokasi. Hal ini dilakukan dengan mengatur lokasi-lokasi tersebut sebagai titik awal dalam proses pembentukan pohon Dijkstra. Misalkan dua lokasi, yaitu lokasi A dan lokasi B ditempatkan sebagai titik yang akan dituju oleh setiap individu (Gambar 6). Selanjutnya individu $m$ ataupun individu lain yang ditempatkan pada titik di graf dapat memilih lintasan terpendek dari dua pohon Dijkstra yang terbentuk. Kedua pohon Dijkstra tersebut dibangun dari titik awal $A$ dan titik awal $B$. 

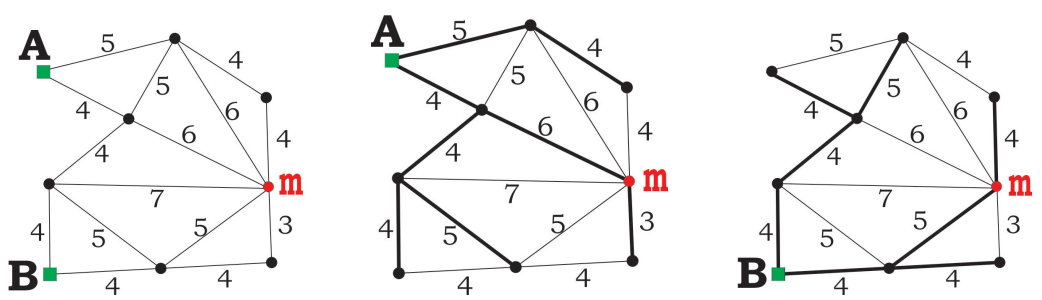

Gambar 6. Graf $G$, Pohon Dijkstra Lokasi $A$ dan Pohon Dijkstra Lokasi $B$

Bobot pada graf $G$ menyatakan jarak diantara dua titik. Lokasi terdekat untuk individu $m$ adalah lokasi $\mathrm{B}$, karena $d(B, m)<d(A, m)$. Hal tersebut berlaku untuk individu lain yang ditempatkan pada titik di graf $G$.

\section{Kesimpulan dan Saran}

Adapun kesimpulan dari makalah ini dapat dijelaskan sebagai berikut

(1) Algoritma Dijkstra merupakan algoritma yang dipakai dalam penentuan lintasan terpendek dari suatu titik tertentu ke setiap titik lain pada suatu graf.

(2) Strategi yang digunakan pada algoritma Dijkstra yaitu dengan membentuk suatu pohon Dijkstra pada setiap pengulangan dengan menggunakan fungsi Dijkstra-nextEdge.

(3) Pohon Dijkstra yang dibentuk setelah pengulangan terakhir merupakan pohon pembangun dari graf awal.

Saran untuk penelitian selanjutnya adalah mengimplementasikan algoritma Dijkstra pada penentuan lintasan terpendek dalam proses evakuasi tsunami.

\section{Ucapan Terima kasih}

Penulis mengucapkan terima kasih kepada Dr. Mahdhivan Syafwan, Dr. Lyra Yulianti, Dr. Effendi, Dr. Admi Nazra, Dr. Haripamyu dan Dr. Des Welyyanti yang telah memberikan masukan dan saran sehingga makalah ini dapat diselesaikan dengan baik.

\section{Daftar Pustaka}

[1] Bondy, J.A. and Murty, U.S.R. 1982. Graph Theory With Applications. Department of Combinatorics and Optimization, University of Waterloo. NorthHolland, New York.

[2] Gross. J. L., J. Yellen. Graph Theory and Its Application Second Edition. Chapman and Hall/CRC.

[3] West. D. B. Introduction to Graph Theory. Mathematics Department, University of Illinois. Prentice Hall Inc, New Jersey. 